\title{
Historical perspectives of The American Association for Thoracic Surgery: John Gordon Scannell (1914-2002)
}

\author{
Cameron D. Wright, MD
}

John Gordon Scannell, the 58th president of The American Association for Thoracic Surgery (AATS), was born in the Jamaica Plain section of Boston on May 13, 1914. His father was a respected surgeon associated with the Boston City Hospital and a teacher of anatomy at Harvard Medical School. Scannell attended Boston Latin School, finishing with a year at Phillips Exeter. He then attended Harvard College and graduated cum laude in 1936. As a Harvard undergraduate and member of the Harvard Lampoon, Harvard's student-run comedic newspaper, he revealed both his literary passion and his wicked sense of humor. He was the unrevealed, but extensively sought, "cunning fellow" who stole the Yale bulldog, shortly thereafter photographed licking the boots of the statue of John Harvard (Figure 1). He graduated from Harvard Medical School

\footnotetext{
From the Massachusetts General Hospital, Boston, Mass.

Received for publication Feb 19, 2011; accepted for publication March 14, 2011; available ahead of print Aug 24, 2011.

Address for reprints: Cameron D. Wright, MD, Thoracic Surgery, Massachusetts General Hospital, Blake 1570, 55 Fruit Street, Boston, MA 02114 (E-mail: wright.cameron@mgh.harvard.edu).

J Thorac Cardiovasc Surg 2012;144:995-7

$0022-5223 / \$ 36.00$

Copyright (C) 2012 by The American Association for Thoracic Surgery doi:10.1016/j.jtcvs.2011.03.038
}

cum laude and received the prize for the highest scholastic average in 1940. He was married that year to Helen Jones, whom he referred to as "The Big H." Helen, in due course, became the mother of 7 children ( 6 girls and 1 boy).

In 1940, Dr Scannell was 1 of 6 surgical interns at the Massachusetts General Hospital (MGH) appointed to the new rectangular 5-year program instituted by Edward D. Churchill, 28th AATS President. Scannell had previously converted his tuberculin test in his fourth year of medical school, which he ascribed to a pathology rotation in which he performed many autopsies on patients who died in sanitariums. In the fall of 1941, fever and lassitude set in, and the night before he was to attend Dr Churchill's tuberculosis surgery clinic, Scannell became quite ill. The following morning, just before clinic, radiography confirmed the extensive spread of tuberculosis in his left upper lobe. Churchill arranged for him to be a private patient at the local Middlesex Sanitarium, where he was placed on bedrest and had an artificial pneumothorax induced. He returned part-time to the residency in the fall of 1942 and full-time in January of 1943. He was declared ineligible for military service because of his tuberculosis.

Not unexpectedly, Scannell gravitated toward thoracic surgery and spent more time than usual with Richard Sweet,
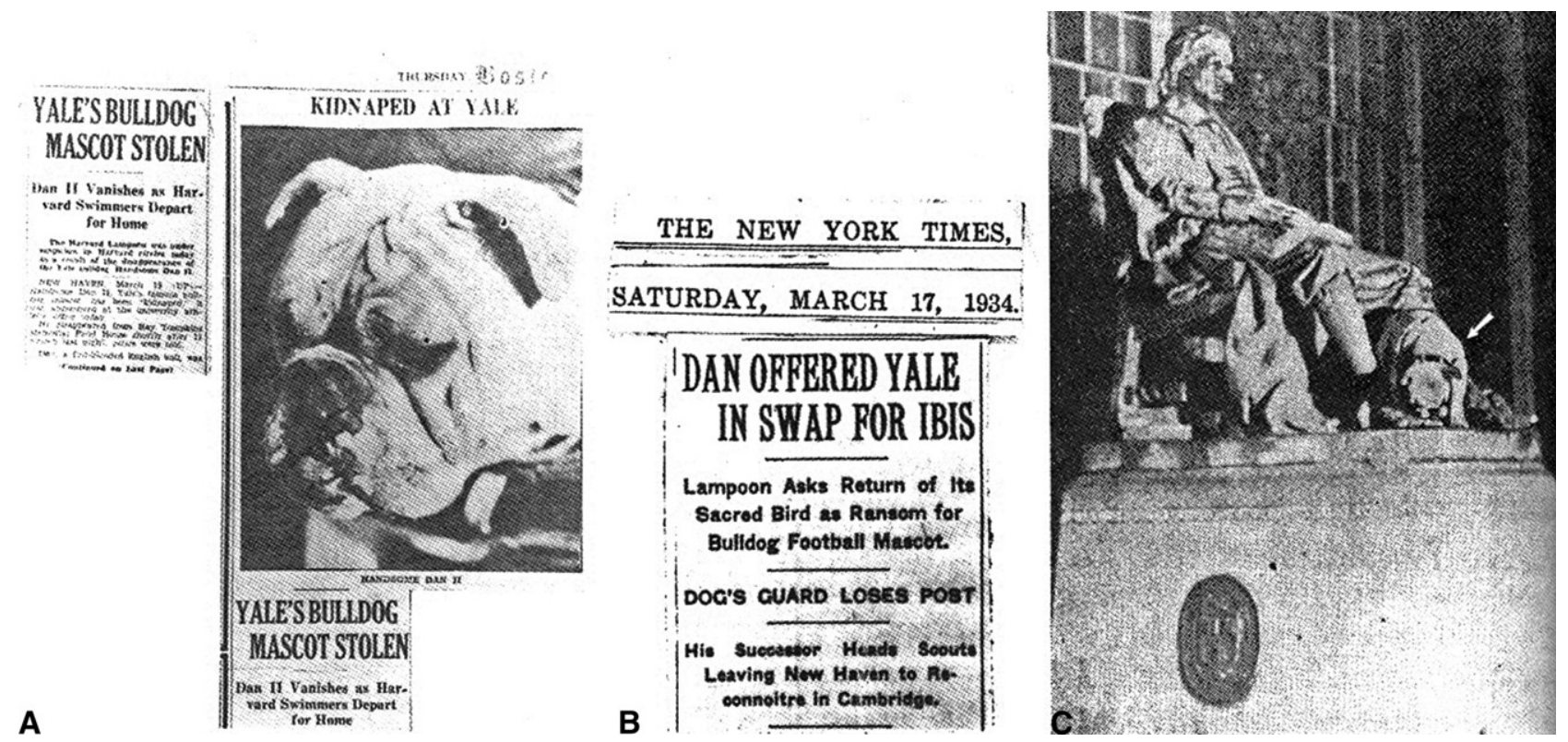

FIGURE 1. The Harvard-Yale bulldog affair. A, The Boston Traveler, March 15, 1934. B, The New York Times, March 17, 1934. C, Boston Herald, April 1, 1934. Handsome Dan (arrow), the Yale mascot, licking the boots of the statue of John Harvard that resides in Harvard Yard (reprinted with permission from Austen WG. Eight former presidents of the AATS. J Thorac Cardiovasc Surg. 1989;98:643-58). 
the designated MGH thoracic surgeon and eventual 41st AATS president. Churchill offered Scannell a faculty position at the MGH after finishing his residency in 1946, before which he was encouraged to take a year off to polish his credentials before starting on staff. Churchill arranged for Scannell to work with Edward Boyden at the University of Minnesota on the segmental anatomy of the lung with a $\$ 4000$ grant from the National Research Council. There he continued his passion for anatomy, studied the bronchovascular anatomy of the upper lobes of the lung, and wrote the definitive anatomic description of the 2 upper lobes. ${ }^{1,2}$ Scannell returned to the MGH in 1947. At that time, Churchill was preoccupied in Washington, DC, with the Hoover Commission, and as a consequence, Scannell essentially ran Churchill's private practice. Scannell functioned as Churchill's right-hand man; other faculty and the residents often went through Scannell to influence Churchill. Scannell was the residency director beginning in 1948, a position he greatly enjoyed. He believed and practiced Churchill's viewpoint that lung cancer could be adequately treated by lobectomy rather than pneumonectomy, and, of course, developed a special interest in surgery for tuberculosis. Early in his practice, he drove to Rutland, Vermont, with Dr Sweet in Sweet's large Cadillac to select cases from a sanitarium to bring down for surgical treatment, most often thoracoplasty. In 1954, coming full circle, patient-to-surgeon, Scannell became the Chief Surgeon at the Middlesex Sanitarium, a position that he held until 1970, although by 1964 cases began to disappear with the advent of more effective antituberculous chemotherapy.

Dr Scannell was involved in cardiac surgery during its early stages. He visited Alfred Blalock, 30th AATS president, at Hopkins in 1948 for several weeks to learn the "Blue Baby" repair. In 1949, he started the cardiac service at the MGH along with Gordon Meyers, a cardiologist. Scannell performed his first closed mitral valvuloplasty in 1951, but unfortunately, his patient died on the table; Scannell was unable to resuscitate the heart. In vascular surgery, Scannell was among the first to report resection and reconstruction of the superior vena cava. ${ }^{3}$ Scannell performed the first open operation at the MGH in 1955, resection of an atrial myxoma. ${ }^{4}$ The patient was a young man from Newfoundland, and the resection was performed without cardiopulmonary bypass using hypothermia $\left(28^{\circ} \mathrm{C}\right)$ to temporarily suspend circulation. After resection, the patient could not be defibrillated. Manual open cardiac massage was performed for more than 2 hours, during which time warm saline was lavaged into his pleural cavities to increase his core temperature. The patient was successfully defibrillated when he reached $30^{\circ} \mathrm{C}$ and recovered uneventfully. He was alive and well when Scannell last saw him as a patient in 1988.

Scannell had a self-admitted mid-life crisis in 1964 and decided to volunteer aboard the SS HOPE, which was

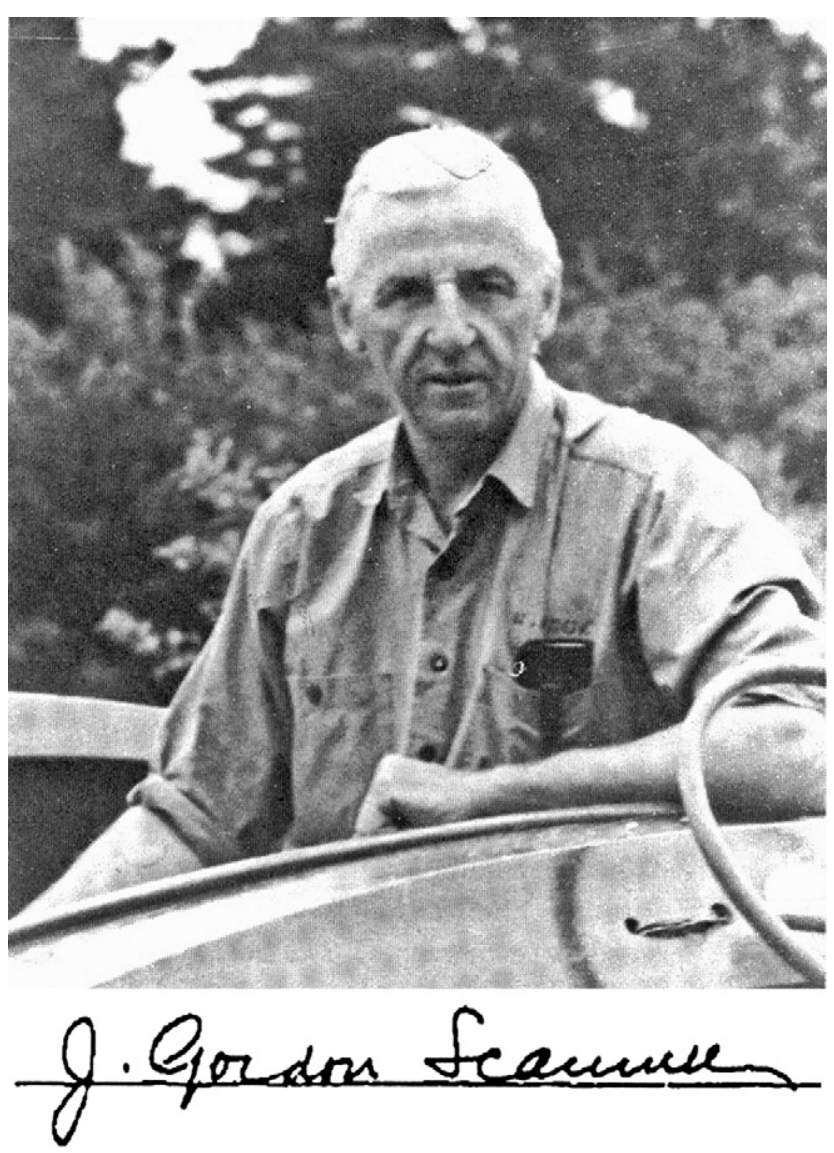

FIGURE 2. J. Gordon Scannell on his boat off Prince Edward Island in 1981 (reprinted with permission from Austen WG. Eight former presidents of the AATS. J Thorac Cardiovasc Surg. 1989;98:643-58).

serving off the coast of the Republic of Guinea in West Africa. As did many others who could not serve during the Second World War, Scannell wanted to go to a foreign land in a humanitarian role. During this 2-month period, he had a life-changing third world medical experience. In 1970, he pulled back from the cardiac service, except for pericardial disease. He described in his memoirs that it was a combination of burnout and the coronary revolution that caused him to give up cardiac surgery (J.G. Scannell, MD, unpublished data, 1988). He maintained an active thoracic surgery practice and became the Director of the Surgical Clerkship for Harvard students at the MGH. In 1980, he was asked to be the editor for the Harvard Medial Alumni Bulletin. He had a scholarly passion for studying and writing medical history, an interest that eventually led him to initiate the "Historical Perspectives" series in the Journal of Thoracic and Cardiovascular Surgery in $1996 .^{5}$

Scannell served on the American Board of Thoracic Surgery and was president of the Boston Surgical Society and New England Surgical Society. In 1978, he delivered his AATS presidential address entitled, "As I Remember 
Them," which was a scholarly, introspective dissertation of 4 famous thoracic surgeons who had a profound influence on him: Leo Eloesser, Alfred Blalock, Richard Sweet, and Edward Churchill. ${ }^{6}$ Scannell published a book about his revered mentor, Edward D. Churchill, entitled Wanderjahr: The Education of a Surgeon, which described Churchill's year abroad in Europe visiting the famous professors of surgery. ${ }^{7}$

Dr Scannell was a lifelong sailor, and in 1978, he sailed across the Atlantic on a 42-foot sloop. He and his wife maintained a summer residence on Prince Edward Island, to which they would retreat whenever possible and sail around Cape Breton Island (Figure 2). He had a wonderful, dry sense of humor, delivered by his speech, but more so by the twinkle in his eye. Dr Scannell had an old-fashioned bedside manner with his patients, for which he was revered. His favorite expressions when referring to his patients, who were often on the elderly side, were to respectfully address them as "this old boy" or "this old girl." Toward the end of his surgical career, Scannell reveled in operating with the thoracic surgery chief resident and regaling him with old stories of the MGH. He was humble and self-deprecating, and carried himself with a grandfather's concern for his patients and residents. Scannell lost Helen in 1998 to breast cancer and developed dementia thereafter. He fell and broke his pelvis and hip in 2002 and died on August 24, 2002, at 88 years of age.

\section{References}

1. Scannell JG. A study of variations of the bronchopulmonary segments in the left upper lobe. J Thorac Surg. 1947;16:530-7.

2. Scannell JG. A study of variations of the bronchopulmonary segments of the right upper lobe. J Thorac Surg. 1948;17:232-7.

3. Scannell JG. Surgical reconstruction of the superior vena cava. J Thorac Surg. 1954;28:163-74.

4. Scannell JG. Successful removal of a myxoma from the left atrium. N Engl J Med. 1956;254:601-4.

5. Scannell JG. Historical perspectives of the American Association for Thoracic Surgery. Samuel J. Meltzer (1851-1920). J Thorac Cardiovasc Surg. 1996;111: 905-6.

6. Scannell JG. As I remember them. J Thorac Cardiovasc Surg. 1978;76:145-57.

7. Churchill ED. Wanderjahr: The Education of a Surgeon. Scannell JG, ed. Boston, MA: The Countway Library; 1990 